\title{
Effect of COVID-19 lockdown on the spatio-temporal distribution of nitrogen dioxide over India
}

\author{
Shuchita Srivastava*, Asfa Siddiqui, D. Mitra and Prakash Chauhan \\ Marine and Atmospheric Sciences Department, Indian Institute of Remote Sensing, Dehradun 248 001, India
}

The nationwide lockdown was implemented in India from 25 March 2020 onwards to control the spread of deadly Coronavirus disease 2019 (COVID-19). A sudden shutdown of anthropogenic activities resulted in abrupt decrease of nitrogen dioxide $\left(\mathrm{NO}_{2}\right)$ across the Indian region. OMI (Ozone Monitoring Instrument) tropospheric column $\mathrm{NO}_{2}$ observations show significantly decreased values during 2020 compared to previous years during 25 March to 19 April. The spatiotemporal variation of tropospheric column $\mathrm{NO}_{2}$ difference between 2020 and average 2017-2019 shows reduction by more than $1 \times 10^{15}$ molecules $/ \mathrm{cm}^{2}$ over the Indo Gangetic Plain, eastern and southern India due to lockdown. However, the western Indian region shows slight enhancement which may be attributed to combined effect of transport of polluted air from Middle East and Pakistan, and relatively higher biomass burning activity during 2020. A significant reduction is also observed on the surface distribution of $\mathrm{NO}_{x}\left(\mathrm{NO}+\mathrm{NO}_{2}\right)$ over different Indian cities due to COVID-19 lockdown. Maximum reduction in daily average surface $\mathrm{NO}_{x}$ is observed over Kolkata (65.2 \pm 18.7 ppbv to $30.3 \pm 4.6 \mathrm{ppbv})$ followed by New Delhi (38.8 $\pm 17.5 \mathrm{ppbv}$ to $11.5 \pm 2.9 \mathrm{ppbv})$ which may be attributed to vehicle fleet, type of fuel used, power plants and industrial emissions.

Keywords: COVID-19 lockdown, nitrogen dioxide, $\mathrm{NO}_{x}$, OMI.

\section{Introduction}

THE ambient air quality is continuously deteriorating over India due to rapid population growth, industrialization, urbanization, economic development and energy consumption $^{1}$. Poor air quality over densely populated regions poses a serious threat to human health and can be a major cause of mortality. Ambient air pollution, contributed to over 1.24 million deaths during 2017 which is $12.4 \%$ of the total deaths in India ${ }^{2}$. One of the criteria pollutants nitrogen dioxide $\left(\mathrm{NO}_{2}\right)$ concentration increased rapidly over the Indian subcontinent in the last two dec$\operatorname{ades}^{3}$. Due to rapid interchangeability, $\mathrm{NO}_{2}$ is jointly stu-

*For correspondence. (e-mail: shuchita@iirs.gov.in) died along with nitric oxide (NO) more commonly known as $\mathrm{NO}_{x}\left(\mathrm{NO}+\mathrm{NO}_{2}\right)$. $\mathrm{NO}_{x}$ catalyses secondary criteria pollutant ozone and affects hydroxyl $(\mathrm{OH})$ radical abundance in the troposphere. As ozone is an important greenhouse gas and $\mathrm{OH}$ radical defines lifetime of several greenhouse gases, increasing $\mathrm{NO}_{x}$ has important climatic implications too ${ }^{4}$. Major sources of nitrogen oxides are fossil fuel combustion (thermal power plants, vehicular activities, industries, etc.), biomass burning, soil nitrification and denitrification and lightning. Major sink of $\mathrm{NO}_{x}$ is oxidation of $\mathrm{NO}_{2}$ by $\mathrm{OH}$ radical to form nitric acid $\left(\mathrm{HNO}_{3}\right)$, which is one of the important components of acid rain ${ }^{4}$.

Nitrogen dioxide can have deleterious impact on human respiratory system. Long term exposure to elevated levels of $\mathrm{NO}_{2}$ may contribute to development of asthma and enhance the susceptibility to respiratory diseases ${ }^{7-9}$. High $\mathrm{NO}_{2}$ exposure is a major cause of respiratory mortality too ${ }^{10,11}$. Long-term exposure to different criteria pollutants including $\mathrm{NO}_{2}$ may be one of the important contributors to mortality caused by the COVID-19 in Europe $^{12,13}$.

COVID-19 started from Wuhan, China in December 2019 and spread across most of the countries in the world by the beginning of March 2020. By first week of March, more than three thousand people died due to this disease worldwide. Considering its fatality, the World Health Organization (WHO) declared it as pandemic on 11 March 2020. Forecasting the possible severity of the outbreak in highly populous region like India, the Indian Government implemented a continuous lockdown for 21 days from 25 March 2020 to 14 April 2020. The lockdown was further extended in different phases with relaxation in those regions which were least affected by the pandemic. A very strict lockdown implementation in last week of March put a sudden full stop on major anthropogenic activities throughout the India. The abrupt drop in the number of vehicles on road, closure of industries and several power plants resulted in significant decrease in pollutants emission specifically $\mathrm{NO}_{2}$ over this populous country. Distribution of criteria pollutant nitrogen dioxide has been investigated before and during lockdown period over the Indian subcontinent using in-situ and satellite based observations. 


\section{Dataset used}

\section{Ozone Monitoring Instrument}

Ozone Monitoring Instrument (OMI) is a spectrometer on board NASA Earth Observing System Aura satellite which measures solar backscattered UV visible radiation over the wavelength range from 270 to $500 \mathrm{~nm}$ with a spectral resolution of about $0.5 \mathrm{~nm}$. OMI has a wide swath of $2600 \mathrm{~km}$, which enables measurements with a daily global coverage. OMI measures total and tropospheric column $\mathrm{NO}_{2}$ using DOAS (Differential Optical Absorption Spectroscopy) in the wavelength range of 405-465 nm. OMI retrieval errors have an absolute component of $\sim 1.0 \times 10^{15}$ molecules $/ \mathrm{cm}^{2}$ and a relative AMF component of $25 \%$ (ref. 14). The horizontal resolution of level 3 tropospheric column $\mathrm{NO}_{2}$ gridded product used in the present study is $0.25^{\circ} \times 0.25^{\circ}$. These observations are obtained from https://giovanni.gsfc.nasa.gov.

\section{$N O_{x}$ surface observations}

Trace level $\mathrm{NO}_{x}$ analyser (42i-TL Thermo Scientific make) is used for the measurement of $\mathrm{NO}_{x}$ in the ambient air over Dehradun $\left(30.3^{\circ} \mathrm{N}, 78.0^{\circ} \mathrm{E}\right)$. The instrument works on the principle that nitric oxide (NO) and ozone $\left(\mathrm{O}_{3}\right)$ react to produce excited state of $\mathrm{NO}_{2}$. The transition of $\mathrm{NO}_{2}$ from excited to ground electronic state produces a characteristic luminescence with an intensity linearly proportional to the NO concentration. For $\mathrm{NO}_{x}$ measurement, $\mathrm{NO}_{2}$ is converted to $\mathrm{NO}$ by a molybdenum $\mathrm{NO}_{2}$ - to

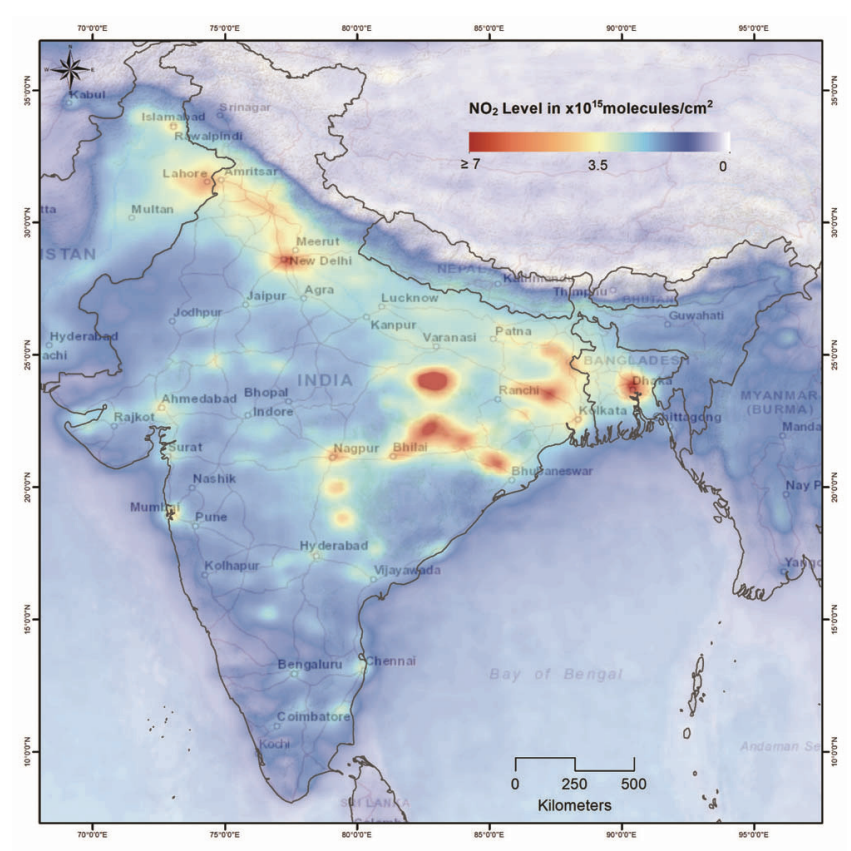

Figure 1. Average tropospheric column $\mathrm{NO}_{2}$ over India during 2018 2020 .
NO converter heated to about $325^{\circ} \mathrm{C}$. The minimum detection limit of this instrument is 50 pptv with noice of 25 pptv. The instrument is calibrated every two to three weeks using zero air generator (Thermofisher Scientific, model no. 1160) and multipoint calibrator (Thermofisher Scientific, model no. 146i). Span gas is obtained from Sigma Gases and Services, New Delhi. The span concentration is diluted below $150 \mathrm{ppbv}$ at different concentrations for the calibration of instrument. The measurement uncertainty of the $\mathrm{NO}_{2}$ exceeds $30 \%$ for $\mathrm{NO}_{2}$ concentrations lower than $20 \mathrm{ppbv}$ and up to $15 \%$ for $100 \mathrm{ppbv}$ (ref. 15). The instrument makes measurement at every 5 min interval $24 \times 7$. Similar instrument is used by the Central Pollution Control Board (CPCB) to make surface measurement of $\mathrm{NO}_{x}$ over different Indian locations. These observations are obtained from www.cpcb.nic.in. The Calibration details on CPCB instruments are available at (https:/cpcb.nic.in/functions-salient-features/). The $\mathrm{NO}_{x}$ observations are analysed over New Delhi (Ashok Vihar), Bengaluru (Jayanagar), Kolkata (Rabindra Bharti University), Hyderabad (Bollaram Industrial Area) and Jaipur (Police Commissionerate). Only those observational sites are chosen where observations were available for 2019 and 2020 both. Further details on these observations can be found elsewhere ${ }^{16}$.

\section{VIIRS 375-m fire product}

The Visible Infrared Imaging Radiometer Suite (VIIRS) is an instrument onboard the Suomi National Polarorbiting Partnership (Suomi NPP) which measures visible to infrared radiation and retrieves different geophysical parameters. The instrument provides fire products at $375 \mathrm{~m}$ resolution using five distinct single-gain channels extending from the visible to thermal infrared spectral region $^{17}$. In the present study, the VIIRS $375 \mathrm{~m}$ fire products obtained from Fire Information for Resource Management System (https://firms.modaps.eosdis.nasa.gov/) are utilized.

\section{Results and discussion}

\section{Average spatial distribution of nitrogen dioxide over India}

Figure 1 shows spatial distribution of tropospheric column $\mathrm{NO}_{2}$ obtained from OMI averaged for two years (2018-2020) over the Indian subcontinent. The figure shows several emission hotspots over populous cities like New Delhi, Mumbai, Kolkata, etc. and in the eastern Indian region. Very high values of tropospheric column $\mathrm{NO}_{2}\left(>7 \times 10^{15}\right.$ molecules $\left./ \mathrm{cm}^{2}\right)$ in the eastern Indian region is associated with emission of coal-based thermal power plants. Figure 2 shows the location of thermal power plants along with their capacity in India 
(https://datasets.wri.org/dataset/globalpowerplantdatabase). These thermal power plants are categorized according to their capacity (less than $1000 \mathrm{MW}$, between 1000 and $2000 \mathrm{MW}$ and more than $2000 \mathrm{MW}$ ). The size of the symbol is proportional to the power generation capacity of power plant. The major emission hotspots shown in OMI tropospheric column $\mathrm{NO}_{2}$ distribution coincide with thermal power plants of capacity more than $2000 \mathrm{MW}$. Coal-based thermal power plants and industrial sectors are largest contributor to India's total $\mathrm{NO}_{x}$ emission $(\sim 50 \%)^{18}$, which is clearly evident from this figure. Excluding emission hotspots, tropospheric column $\mathrm{NO}_{2}$ shows relatively higher concentration of $\mathrm{NO}_{2}$ over the Indo Gangetic Plain with respect to the remaining Indian region. This region is densely populated and hence heavily polluted mainly due to transport and domestic cooking activities ${ }^{19}$.

\section{Satellite-based observations during lockdown}

Effect of nationwide lockdown has been investigated using OMI tropospheric column $\mathrm{NO}_{2}$ distribution. Figure 3 shows the spatial distribution of average tropospheric column $\mathrm{NO}_{2}$ over the Indian subcontinent for the period of 1-24 March (before lockdown), 25 March-19 April (strict lockdown), 20 April-2 May (relaxed lockdown phase 1) and 3-15 May (relaxed lockdown phase 2) during 2020. The average spatial distribution of tropospheric column $\mathrm{NO}_{2}$ before the lockdown period shows very high values throughout the Indian region with several hotspots in the eastern, north-east Indian and Myanmar regions.
The high $\mathrm{NO}_{2}$ values over Northeast India and Myanmar may be attributed to slash and burn agriculture practice over these regions ${ }^{20,21}$. Figure $3 b$ shows the tropospheric column $\mathrm{NO}_{2}$ during the strict lockdown phase (25 March to 19 April 2020). This figure shows a significant drop in tropospheric column $\mathrm{NO}_{2}$ values throughout the Indian region including emission hotspots. Only four emission hotspots are visible in Chhattisgarh and Odisha. All these four high $\mathrm{NO}_{2}$ locations are observed in close vicinity of coal-based thermal power plants of capacity more than $2000 \mathrm{MW}$. India's energy consumption has fallen by $30 \%$ due to COVID-19 lockdown (https://www.iea.org/reports/ global-energy-review-2020). This resulted in closure of several thermal power plants except four super power plants of capacity more than $2000 \mathrm{MW}$. Their emissions are observed by OMI as seen in Figure 3.

During relaxed lockdown phase 1 and phase 2, the tropospheric concentration of $\mathrm{NO}_{2}$ increases throughout the India specifically over Punjab, Haryana and Uttar Pradesh (Figure $3 c$ and $d$ ). This feature is more prominent in the second phase of relaxed lockdown over Punjab. This may be associated with wheat crop residue burning over this region. Wheat is sown during November-December and harvested during April-May in Punjab. Wheat crop residue burning is generally practiced as it is a quicker and economical option for management of stubble $^{22,23}$.

It is interesting to note that tropospheric column $\mathrm{NO}_{2}$ concentration decreases at four hotspots regions during relaxed lockdown phase 1 and phase 2 . This again confirms the reduced power consumption in India during

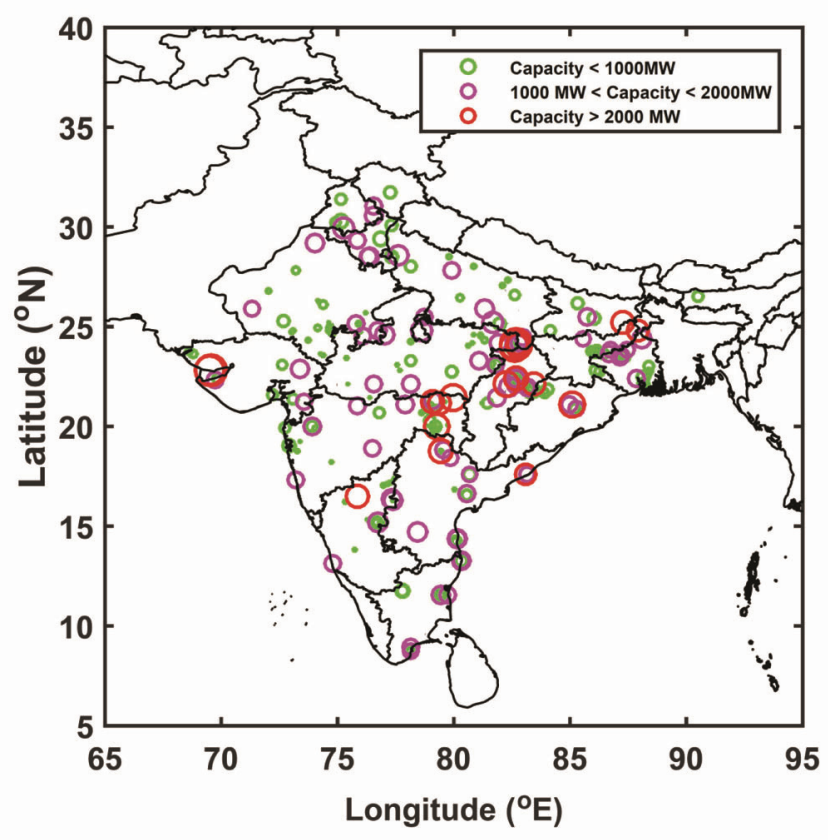

Figure 2. Location of coal-based thermal power plants in India.
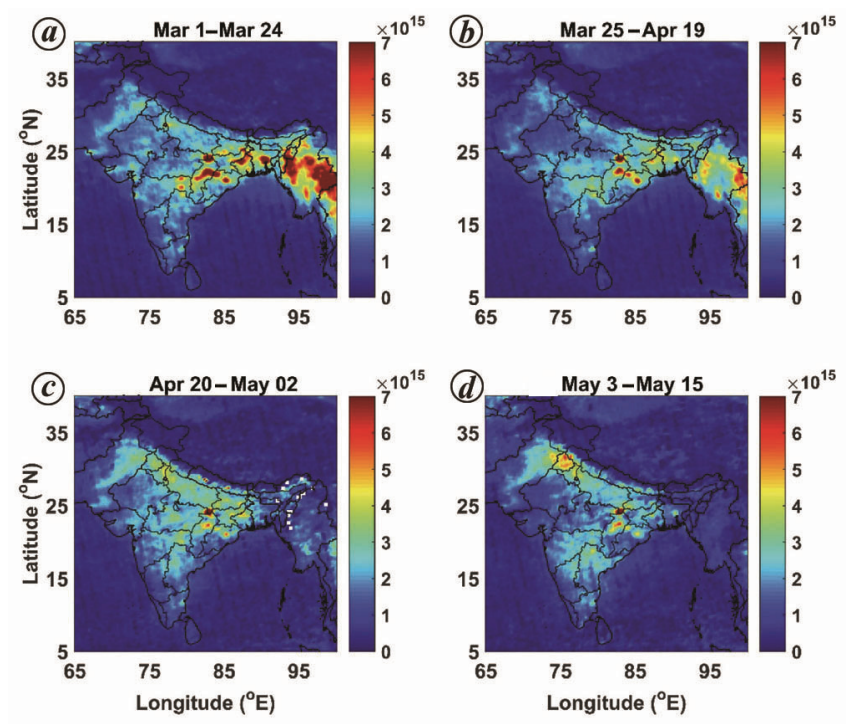

Figure 3. Tropospheric column $\mathrm{NO}_{2}\left(\right.$ molecules $\left./ \mathrm{cm}^{2}\right)$ for a period of (a) 1-24 March (before lockdown), (b) 25 March-19 April (strict lockdown), (c) 20 April-2 May (relaxed lockdown phase 1) and (d) 3 May-15 May (relaxed lockdown phase 2) during 2020 over the Indian subcontinent. 
lockdown phase. Low values of tropospheric column $\mathrm{NO}_{2}$ can be observed over Gujarat, West Bengal and Bangladesh during the second phase of relaxed lockdown which may be associated with changing meteorology during spring season $^{24,25}$.

To avoid the effect of changing meteorology with time, the spatial distribution of average tropospheric column $\mathrm{NO}_{2}$ for a period of 25 March to 19 April 2020 is compared with observations made during exact same time period in 2017, 2018 and 2019. Figure 4 shows three year averaged (2017-2019) spatial distribution of tropospheric column $\mathrm{NO}_{2}$ for a period of 25 March to 19 April and spatial distribution of tropospheric column $\mathrm{NO}_{2}$ for a period of 25 March-19 April 2020. The tropospheric column $\mathrm{NO}_{2}$ is relatively much lower in 2020 compared to previous years. The difference between 2020 and average 2017-2019 shown in Figure $4 c$ indicates that tropospheric column $\mathrm{NO}_{2}$ values decreased by more than $1 \times 10^{15}$ molecules $/ \mathrm{cm}^{2}$ over the Indo Gangetic Plain, eastern and southern India. In Figure $4 d$, the tropospheric column $\mathrm{NO}_{2}$ reduction due to lockdown (average 2017 2019 observation minus 2020 observation) is compared with 1 sigma standard deviation in tropospheric column $\mathrm{NO}_{2}$ during 2017-2019 to investigate if the lockdown related reduction is beyond interannual variability in tropospheric column $\mathrm{NO}_{2}$. The reduction greater than 1 sigma standard deviation is shown by positive values. The figure reveals that reduction is higher than 1 sigma standard
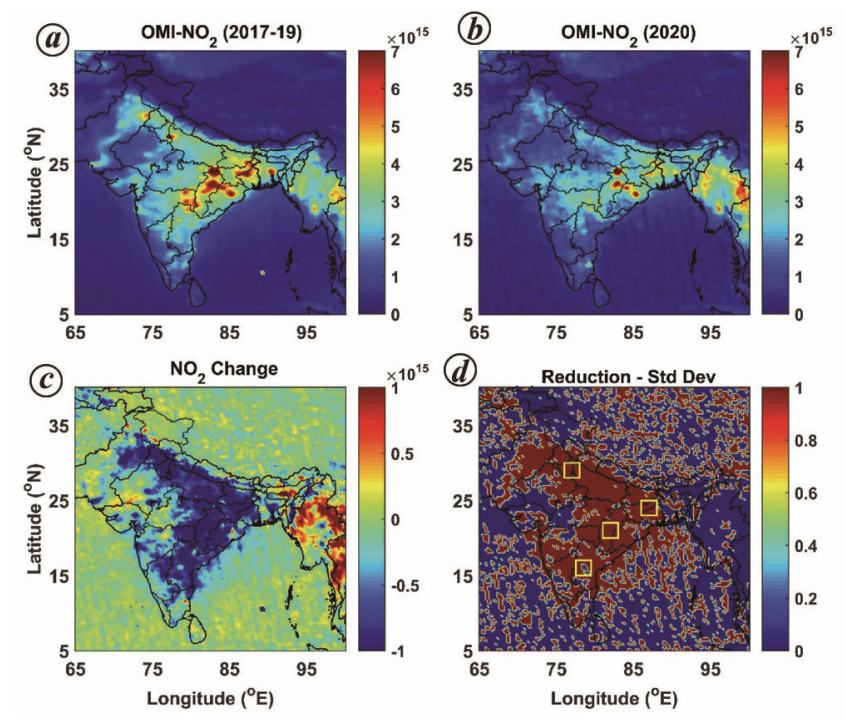

Figure 4. $\boldsymbol{a}$, Three-year average (2017-2019) tropospheric column $\mathrm{NO}_{2}$ (molecules $/ \mathrm{cm}^{2}$ ) for a period of 25 March to 19 April. $\boldsymbol{b}$, Tropospheric column $\mathrm{NO}_{2}$ for a period of 25 March to 19 April 2020. $c$, Tropospheric column $\mathrm{NO}_{2}$ difference (2020 minus 2017-2019 average). $\boldsymbol{d}$, Comparison of reduction in tropospheric column $\mathrm{NO}_{2}$ (2017-2019 average minus 2020 observations) with one sigma standard deviation (calculated for 2017-2019). Reduction greater than one sigma standard deviation is shown by positive values. Four $2^{\circ} \times 2^{\circ}$ geographical regions over northern, central-eastern, eastern and southern Indian region are also shown. deviation over most of the Indian region except western India.

As the observed reduction is close to the retrieval error $\left(1 \times 10^{15}\right.$ molecules $\left./ \mathrm{cm}^{2}\right)$ of OMI, the reliability of reduction in tropospheric column $\mathrm{NO}_{2}$ is further investigated. Four $2^{\circ} \times 2^{\circ}$ square regions are chosen over northern, southern, eastern and central-eastern Indian regions. Geographical location of these regions is shown in Figure $4 d$. Daily average tropospheric column $\mathrm{NO}_{2}$ for the strict lockdown phase during 2020 and average 2017-2019 is shown in Figure 5. The difference is more than $1 \times$ $10^{15}$ molecules $/ \mathrm{cm}^{2}$ for most of days over northern, central-eastern and eastern Indian regions whereas for few days over southern India. This shows that reduction is beyond the retrieval error of OMI specifically over northern, central-eastern and eastern Indian regions.

The tropospheric column $\mathrm{NO}_{2}$ shows slight enhancement over western India despite strict lockdown throughout the country (Figure $4 c$ ). This may be associated with transport of polluted air from upwind regions and relatively higher biomass burning activity in western India during the lockdown period. Figure $6 a$ shows the average wind pattern obtained from ECMWF (European Centre for Medium Range Weather Forecast, data obtained

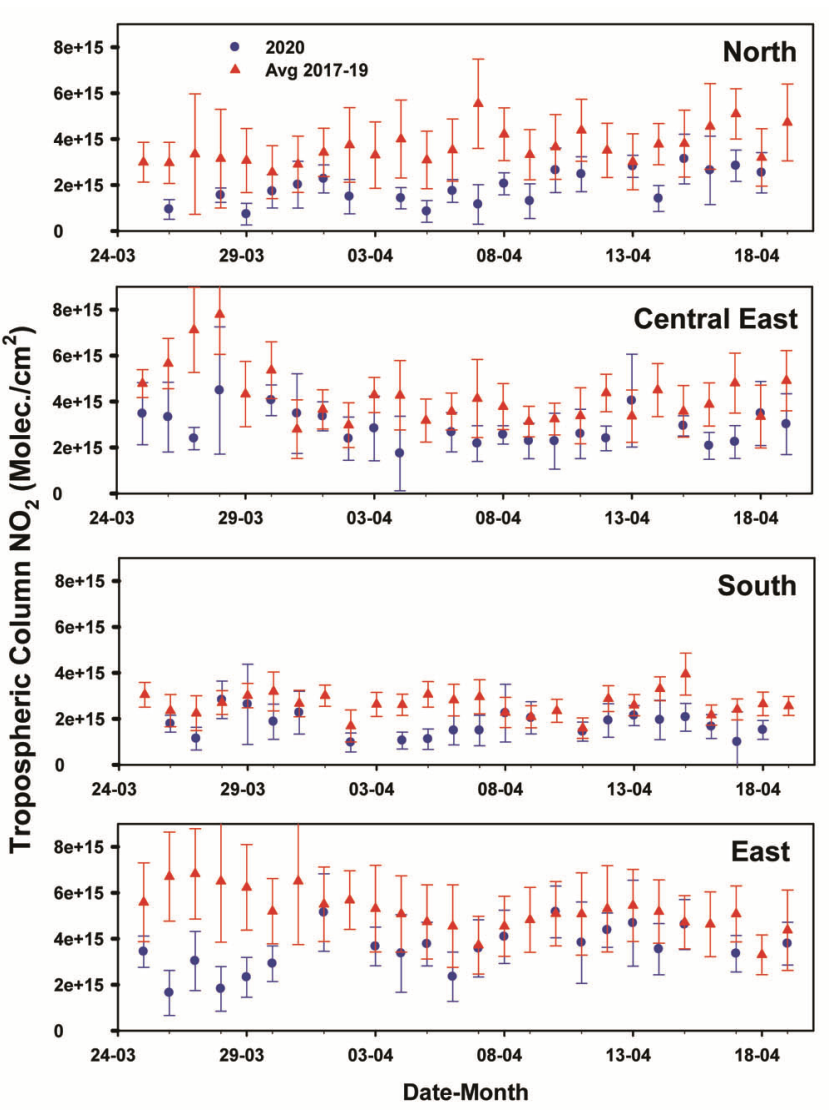

Figure 5. Daily variation of three-year average (2017-2019) tropospheric column $\mathrm{NO}_{2}$ and 2020 tropospheric column $\mathrm{NO}_{2}$ during 25 March to 19 April over northern, central-eastern, eastern and southern Indian regions. 

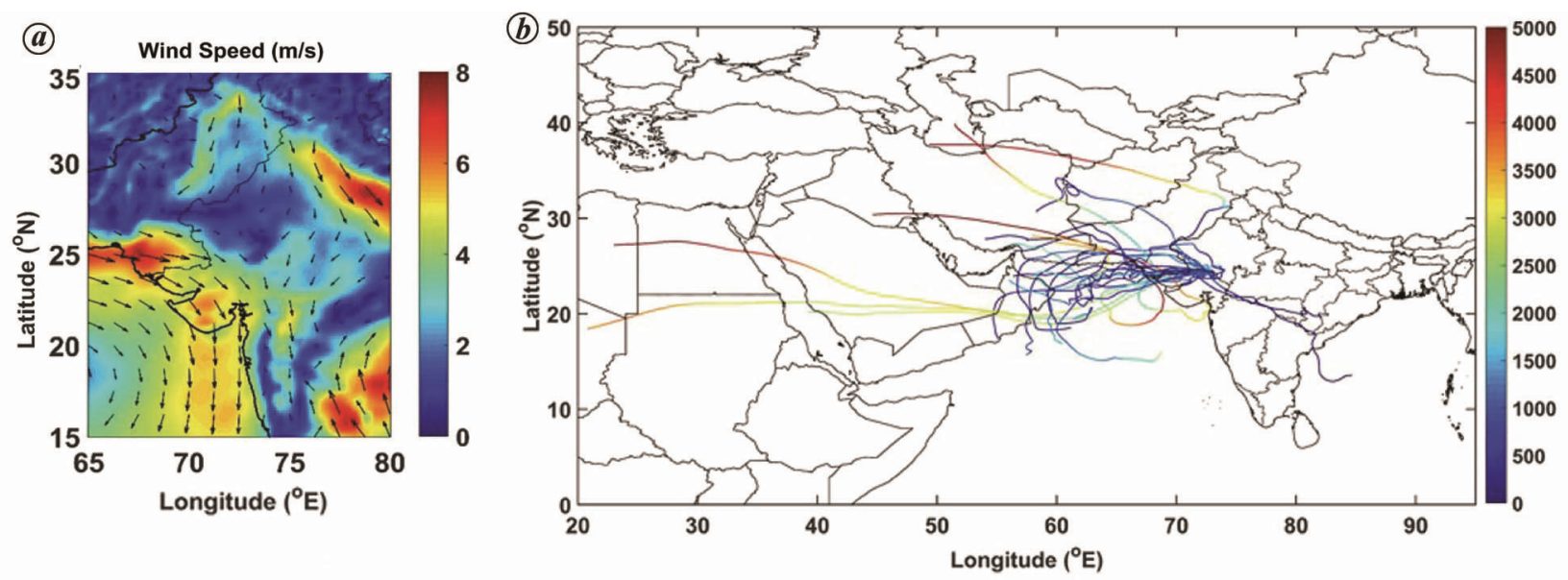

(m)

Figure 6. $\boldsymbol{a}$, ECMWF winds at $925 \mathrm{hPa}$ over the western Indian region during 25 March to 19 April 2020. $\boldsymbol{b}$, Seven days back trajectories arriving at $1 \mathrm{~km}$ over a western Indian location $\left(24.5^{\circ} \mathrm{N}, 72.5^{\circ} \mathrm{E}\right)$ for each day during 25 March-19 April 2020. Colour bar shows altitude (metre) of the air parcel.
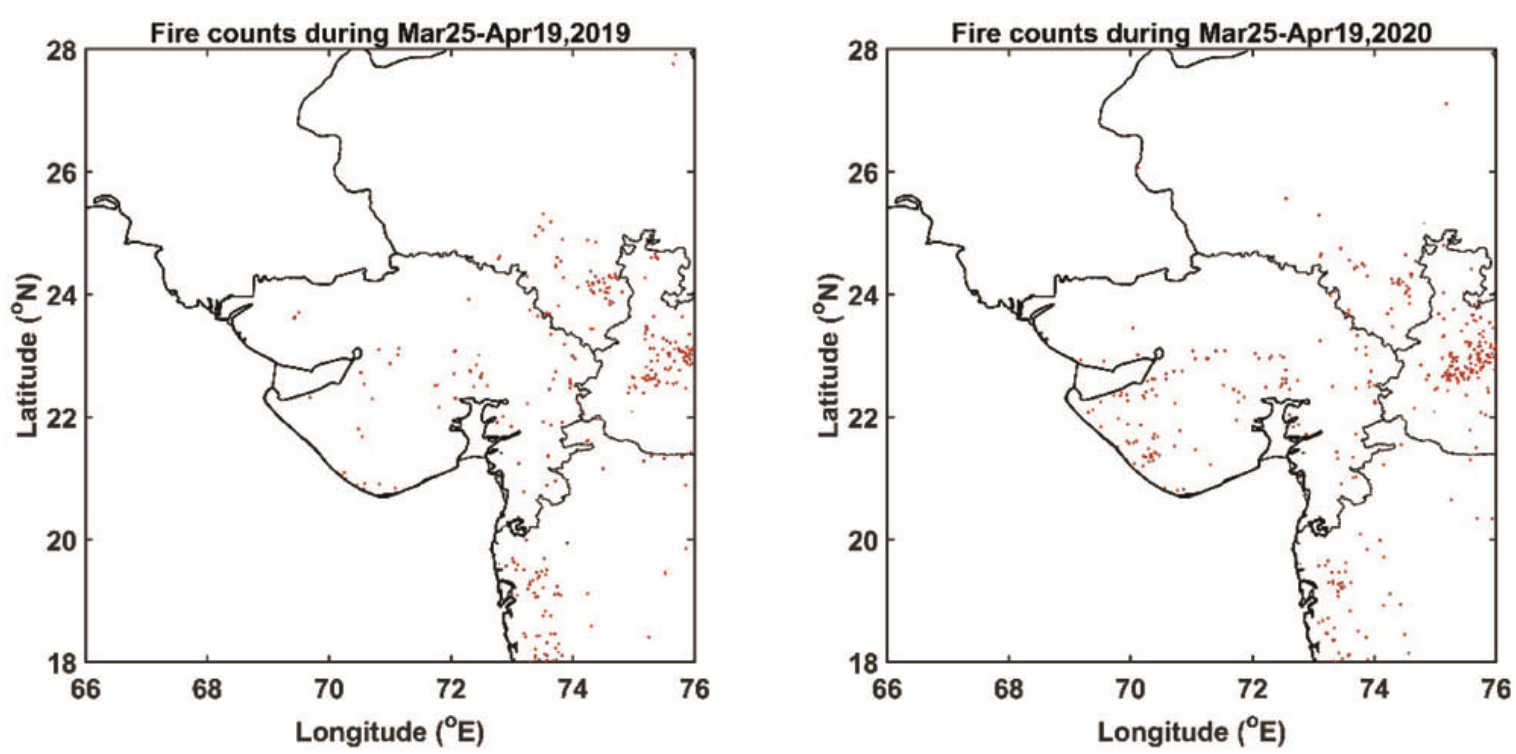

Figure 7. VIIRS fire counts during 25 March-19 April 2019 and 25 March-19 April 2020.

from https://cds.climate.copernicus.eu) at $925 \mathrm{hPa}$ over the western Indian region during 25 March-19 April 2020. Prevailing winds are westerly and northerly over this region and wind speed is also very high specifically near Gujarat border. Figure $4 c$ shows that tropospheric column $\mathrm{NO}_{2}$ difference over western India is similar to tropospheric column $\mathrm{NO}_{2}$ difference over upwind Pakistan and Arabian Sea region. This further indicates that transport may be one of the reasons of tropospheric column $\mathrm{NO}_{2}$ enhancement over the western Indian region. To investigate the probable source region, seven days back trajectories are calculated using Hysplit model (https://www.ready.noaa.gov/HYSPLIT.php) at a western Indian location $\left(24.5^{\circ} \mathrm{N}, 72.5^{\circ} \mathrm{E}\right.$, starting altitude $1000 \mathrm{~m} \mathrm{AGL}$ ) at $6 \mathrm{GMT}$ for each day during the strict lockdown phase (Figure $6 \mathrm{~b}$ ). The back trajectories sug- gest that Middle East (Saudi Arabia, Oman, Iran) and Pakistan may be probable source regions for enhancement of tropospheric columnar $\mathrm{NO}_{2}$ over this region. Relatively higher biomass burning activity during 2020 with respect to 2019 over western India may be the other possible reason. Figure 7 shows VIIRS fire counts for 25 March-19 April 2019 and 2020 over the western Indian region. Only high confidence fire counts are considered in the present study. The figure clearly shows relatively high fire counts during 2020. This may be associated with rabi crop residue burning over this region ${ }^{26}$. Total fire counts and fire radiative power is estimated within the rectangular region bounded by $20-26^{\circ} \mathrm{N}$ and $68-76^{\circ} \mathrm{E}$ over the western India. Total fire counts are found to be 327 and 400 and fire radiative power is found to be $4685 \mathrm{MW}$ and 5719 MW during 2019 and 2020 respectively. This 
Table 1. Daily average $\mathrm{NO}_{x}$ concentration before and during lockdown period 2020 and during 25 March-19 April 2019 over different Indian cities

\begin{tabular}{lccc}
\hline City & $\begin{array}{c}\text { Before lockdown } \\
(1-24 \text { March 2020) }\end{array}$ & $\begin{array}{c}\text { During strict lockdown } \\
(25 \text { March-19 April 2020) }\end{array}$ & $\begin{array}{c}\text { During } \\
\text { 25 March-19 April 2019 }\end{array}$ \\
\hline New Delhi & $38.8 \pm 17.5 \mathrm{ppbv}$ & $11.5 \pm 2.9 \mathrm{ppbv}$ & $44.9 \pm 16.8 \mathrm{ppbv}$ \\
Bengaluru & $24.4 \pm 7.5 \mathrm{ppbv}$ & $10.1 \pm 2.5 \mathrm{ppbv}$ & $23.0 \pm 3.9 \mathrm{ppbv}$ \\
Kolkata & $65.2 \pm 18.7 \mathrm{ppbv}$ & $30.3 \pm 4.6 \mathrm{ppbv}$ & $53.1 \pm 31.8 \mathrm{ppbv}$ \\
Hyderabad & $14.6 \pm 3.8 \mathrm{ppbv}$ & $8.9 \pm 1.1 \mathrm{ppbv}$ & $14.3 \pm 4.0 \mathrm{ppbv}$ \\
Jaipur & $30.2 \pm 13.1 \mathrm{ppbv}$ & $10.1 \pm 2.8 \mathrm{ppbv}$ & $38.6 \pm 13.2 \mathrm{ppbv}$ \\
Dehradun & $5.1 \pm 1.2 \mathrm{ppbv}$ & $2.3 \pm 0.2 \mathrm{ppbv}$ & $7.3 \pm 1.1 \mathrm{ppbv}$ \\
\hline
\end{tabular}
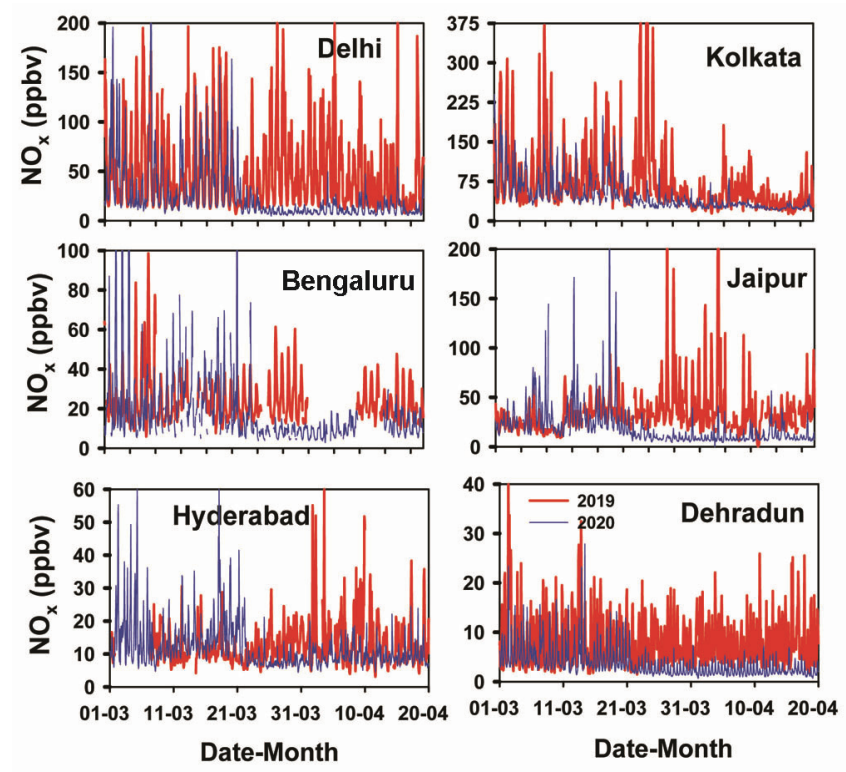

Figure 8. Time series variation of hourly average $\mathrm{NO}_{x}$ over different Indian cities during 1 March-19 April in 2019 and 2020.

suggests that crop residue burning might have played an important role in $\mathrm{NO}_{2}$ enhancement during lockdown period over western India.

\section{Surface observations of $N O_{x}$ over different Indian cities}

Lockdown-related reduction in $\mathrm{NO}_{x}$ emission is also studied using surface measurements of $\mathrm{NO}_{x}$ over six Indian cities namely New Delhi, Bengaluru, Kolkata, Hyderabad, Jaipur and Dehradun. Figure 8 shows the variation of hourly average $\mathrm{NO}_{x}$ from 1 March to 19 April during 2019 as well as during 2020 over these cities. The effect of strict lockdown is clearly seen as $\mathrm{NO}_{x}$ shows significant decrease after 25 March 2020 over all these observational locations.

Table 1 shows the comparison between daily average concentration of $\mathrm{NO}_{x}$ before and during strict lockdown phase during 2020 and also during 25 March-19 April 2019. Maximum $\mathrm{NO}_{x}$ concentration is observed over
Kolkata $(65.2 \pm 18.7 \mathrm{ppbv})$ followed by New Delhi $(38.8 \pm 17.5 \mathrm{ppbv})$ before the lockdown implementation. After lockdown, the daily average concentration decreased to $30.3 \pm 4.6 \mathrm{ppbv}$ and $11.5 \pm 2.9 \mathrm{ppbv}$ over these cities respectively. Similar decrease is also observed over Bangalore $(24.4 \pm 7.5 \mathrm{ppbv}$ to $10.1 \pm 2.5 \mathrm{ppbv})$, Hyderabad (14.6 $\pm 3.8 \mathrm{ppbv}$ to $8.9 \pm 1.1 \mathrm{ppbv})$, Jaipur $(30.2 \pm$ 13.1 to $10.1 \pm 2.8)$ and Dehradun $(5.1 \pm 1.2 \mathrm{ppbv}$ to $2.3 \pm 0.2 \mathrm{ppbv}$ ) with lower magnitude. Observations for the year 2020 are also compared with 2019 observations. It is interesting to note that $\mathrm{NO}_{x}$ observations before 25 March during 2020 and after 25 March in 2019 do not show much variation (within $13 \mathrm{ppbv}$ for all sites). This analysis further confirms that significant reduction in surface values of $\mathrm{NO}_{x}$ after 25 March 2020 is associated with reduced anthropogenic emission due to implementation of lockdown to contain COVID-19.

Maximum $\mathrm{NO}_{x}$ reduction is observed over Kolkata followed by New Delhi, two megacities in IGP having population over 10 million (Census, 2011). New Delhi has 88.5 lakh vehicles and 2 thermal power plants whereas Kolkata has 7.4 lakh vehicles and 3 thermal power plants ${ }^{27}$. Despite having large number of vehicles, relatively lower $\mathrm{NO}_{x}$ pollution over New Delhi may be attributed to use of cleaner fuel $\mathrm{CNG}$ in public transport whereas the public transport in Kolkata depends on diesel. In addition, road space available for transport is only $6 \%$ over Kolkata which causes congestion, reduces the average vehicular speed and results in heavy vehicular emission ${ }^{28}$. In addition, emission from thermal power plants and small scale industries also badly influences the $\mathrm{NO}_{x}$ level over Kolkata ${ }^{29}$. Thus COVID induced lockdown shows maximum influence over Kolkata followed by New Delhi.

\section{Implications of $\mathrm{NO}_{x}$ reduction during COVID-19 related lockdown}

The COVID-19-related lockdown has given an excellent opportunity to understand the tropospheric photochemistry with bare minimal influence of anthropogenic activities. Spring is a season of extensive biomass burning in Northern and North Eastern Indian region ${ }^{20,23}$. In the 
absence of major anthropogenic activities, influence of biomass burning on $\mathrm{NO}_{x}$ distribution can be studied in detail. Production of ozone is nonlinearly dependent on $\mathrm{NO}_{x}$ and volatile organic compounds. Several modelbased studies are performed with altered emissions to investigate the influence of changing concentration of its precursors on ozone concentration over different regions $^{30}$. For the first time, model based study can be carried out using reduced anthropogenic emissions and can be compared with real time observations. Development of effective emission control strategies over highly populated Indian region remains a challenge to attain the National Ambient Air Quality Standard (NAAQS). The in-situ observations of $\mathrm{NO}_{x}$ along with other pollutants during lockdown have shown improved air quality almost immediately after the lockdown implementation ${ }^{31}$. These observations suggest that short span complete lockdown over urban/industrial cities may be efficient for controlling the ambient air pollution particularly during high pollution episodes (like over Delhi during winter).

\section{Summary and conclusion}

The national lockdown was implemented in India from 25 March 2020 onwards to control COVID-19 spread. This resulted in a sudden drop in anthropogenic emissions and significantly improved the air quality over India. The criteria air pollutant $\mathrm{NO}_{2}$ shows abrupt decrease over the Indian region immediately after the lockdown implementation. Satellite based $\mathrm{NO}_{2}$ tropospheric column observations show significantly decreased values during 2020 compared to previous years during the lockdown phase. The city level emission hotspots completely disappeared from spatial distribution of tropospheric column $\mathrm{NO}_{2}$. The spatio-temporal variation of tropospheric column $\mathrm{NO}_{2}$ difference between 2020 and average 2017-2019 shows that values decreased by more than $1 \times$ $10^{15}$ molecules $/ \mathrm{cm}^{2}$ over the Indo Gangetic Plain, eastern and southern India due to lockdown. However, after relaxation in lockdown, the tropospheric column $\mathrm{NO}_{2}$ is found to increase over Punjab, Haryana and Uttar Pradesh significantly. This increase is more prominent over Punjab during second phase of relaxed lockdown (3 May to 15 May 2020). This may be attributed to wheat crop residue burning.

Despite strict lockdown, tropospheric columnar $\mathrm{NO}_{2}$ slightly increased over western India during the strict lockdown phase. Study suggests that it may be a combined effect of transport of polluted air from Middle East and Pakistan, and higher crop residue burning over western India during 2020 with respect to previous year.

Effect of COVID-19 lockdown is also observed on the surface distribution of $\mathrm{NO}_{x}$ over different Indian cities. After implementation of lockdown, the daily average $\mathrm{NO}_{x}$ mixing ratio shows a decrease from $65.2 \pm 18.7 \mathrm{ppbv}$ to $30.3 \pm 4.6 \mathrm{ppbv}$ over Kolkata, $38.8 \pm 17.5 \mathrm{ppbv}$ to $11.5 \pm 2.9 \mathrm{ppbv}$ over New Delhi, $24.4 \pm 7.5 \mathrm{ppbv}$ to $10.1 \pm 2.5$ ppbv over Bengaluru, $14.6 \pm 3.8$ ppbv to $8.9 \pm$ $1.1 \mathrm{ppbv}$ over Hyderabad, $30.2 \pm 13.1$ to $10.1 \pm 2.8 \mathrm{ppbv}$ over Jaipur and $5.1 \pm 1.2$ ppbv to $2.3 \pm 0.2$ ppbv over Dehradun. A comparison of daily average values before lockdown phase in 2020 and after 25 March 2019 shows almost similar mixing ratios of $\mathrm{NO}_{x}$. This confirms that decreased $\mathrm{NO}_{x}$ surface values during strict lockdown phase in 2020 are associated with reduced anthropogenic activities.

The nationwide lockdown was a temporary phase, and satellite observations show increased $\mathrm{NO}_{x}$ emission after relaxation in lockdown during May 2020. But this phase gave a unique opportunity to quantify the anthropogenic influence on $\mathrm{NO}_{x}$ emissions over entire Indian region using real time observations for the first time. These observations will be useful for policy makers for the development of a proper mitigation strategy to control the rapid pollution growth over the Indian region.

1. Kurokawa, J. and Ohara, T., Long-term historical trends in air pollutant emissions in Asia: Regional Emission inventory in ASia (REAS) version 3.1. Atmos. Chem. Phys. Discuss., 2019; https://doi.org/10.5194/acp-2019-1122.

2. Balakrishnan, K. et al., The impact of air pollution on deaths, disease burden, and life expectancy across the states of India: the Global Burden of Disease Study. Lancet Planetary Health, 2017, 5196(18), 30261-30244.

3. Mahajan, A. S., Smedt, I. De, Biswas, M. S., Ghude, S. D., Fadnavis, S., Roy, C. and Roozendael, M. van, Inter-annual variations in satellite observations of nitrogen dioxide and formaldehyde over India. Atmos. Environ., 2015, 116, 194-201.

4. IPCC, Climate Change, Atmospheric Chemistry and Greenhouse Gases, Contribution of Working Group I to the Third Assessment Report of the Intergovernmental Panel on Climate Change, 2001.

5. Khreis, H., Kelly, C., Tate, J., Parslow, R., Lucas, K. and Nieuwenhuijsen, M., Exposure to traffic-related air pollution and risk of development of childhood asthma: a systematic review and meta-analysis. Environ. Int., 2017, 100, 1-31.

6. Khreis, H. and Nieuwenhuijsen, M. J., Traffic-related air pollution and childhood asthma: recent advances and remaining gaps in the exposure assessment methods. Int. J. Environ. Res. Public Health, 2017, 14(3), 312; https://doi.org/10.3390/ijerph14030312

7. Abbey, D. E., Colome, S. D., Mills, P. K., Burchette, R., Beeson, W. L. and Tian, Y., Chronic disease associated with long-term concentrations of nitrogen dioxide. J. Expo. Anal. Environ. Epidemiol., 1993, 3, 181-202.

8. Blomberg, A. et al., Persistent airway inflammation but accommodated antioxidant and lung function responses after repeated daily exposure to nitrogen dioxide. Am. J. Respir. Crit. Care Med., 1999, 159, 536-543.

9. Chen, T. M., Kuschner, W. G., Gokhale, J. and Shofer, S., Outdoor air pollution: nitrogen dioxide, sulfur dioxide, and carbon monoxide health effects. Am. J. Med. Sci., 2007, 333, 249-256.

10. Beelen, R. et al., Long-term effects of traffic-related AIR pollution. Environ. Health Persp., 2008, 116(2), 196-202.

11. Hoek, G., Krishnan, R. M., Beelen, R., Peters, A., Ostro, B., Brunekreef, B. and Kaufman, J. D., Long-term air pollution exposure and cardio-respiratory mortality: a review. Environ. Health, 2013, 12, 43 . 
12. Bilal, Bashir, M. F. et al., Environmental pollution and COVID-19 outbreak: insights from Germany. Air Qual. Atmos. Health, 2020, 1-10; doi:10.1007/s11869-020-00893-9

13. Conticini, E., Frediani, B. and Caro, D., Can atmospheric pollution be considered a co-factor in extremely high level of SARSCoV-2 lethality in Northern Italy?*. Environ. Pollut., 2020, 261, 114465 .

14. Boersma, K. F. et al., An improved retrieval of tropospheric $\mathrm{NO}_{2}$ columns from the Ozone Monitoring Instrument, Atmos. Meas. Tech., 2011, 4, 1905-1928.

15. Gerboles, M., Lagler, F., Rembges, D. and Brun, C., Assessment of uncertainty of $\mathrm{NO}_{2}$ measurements by the chemiluminescence method and discussion of the quality objective of the $\mathrm{NO}_{2}$ European Directive. J. Environ. Monitoring, 2003, 5, 529-540.

16. Harrison, R. M. and Perry, R., Handbook of Air pollution Analysis, Chapman Hall, New York, 1986, 2nd edn.

17. Schroeder, W., Oliva, P., Giglio, L. and Csiszar, I. A., The New VIIRS $375 \mathrm{~m}$ active fire detection data product: Algorithm description and initial assessment. Rem. Sens. Environ., 2014, 143, 85-96.

18. Garg, A., Shukla, P. R., Bhattacharya, S. and Dadhwal, V. K., Sub-region (district) and sector level $\mathrm{SO}_{2}$ and $\mathrm{NO}_{x}$ emissions for India: Assessment of inventories and mitigation flexibility. Atmos. Environ., 2001, 35, 703-713.

19. Beig, G. and Ali, K., Behavior of boundary layer ozone and its precursors over a great alluvial plain of the world: Indo-Gangetic Plains. Geophys. Res. Lett., 2006, 33, L24813; doi:10.1029/ 2006GL028352.

20. Periaswamy, P. et al., Shifting cultivation in North East India: Social dimension, cross cultural reflection and strategies for improvement. Indian J. Agric. Sci., 2018, 88, 811-819.

21. Yadav, P. K., Slash-and-burn agriculture in North-East India. Exp. Op. Environ. Biol., 2013, 2; 10.4172/2325-9655.1000102.

22. Singh, R. P. and Kaskaoutis, D. G., Crop residue burning: a threat to South Asian air quality. EOS Trans. Am. Geophys. Union, 2014, 95(37), 333-340.

23. Vadrevu, K. P., Ellicott, E. and Badarinath, K., MODIS derived fire characteristics and aerosol optical depth variations during the agricultural residue burning season, North India. Environ. Pollut., 2011, 159(6), 1560-1569.

24. Mallik, C. et al., Variability of $\mathrm{SO}_{2}, \mathrm{CO}$, and light hydrocarbons over a megacity in Eastern India: effects of emissions and transport. Environ. Sci. Pollut. Res., 2014, 21, 8692-8706.

25. Srivastava, S., Lal, S., Subrahamanyamb, D. B., Gupta, S., Venkataramani, S. and Rajesh, T. A., Seasonal variability in mixed layer height and its impact on trace gas distribution over a tropical urban site: Ahmedabad. Atmos. Res., 2010, 96, 79-87.

26. Jain, N., Bhatia, A. and Pathak, H., Emission of air pollutants from crop residue burning in India. Aerosol Air Quality Res., 2014, 14, 422-430.

27. Road Transport Year Book 2015-16, Transport Research Wing, Ministry of Road Transport and Highways, Government of India.

28. West Bengal Pollution Control Board, Annual Report 2008-2010; Government of West Bengal, Kolkata, India, 2010.

29. Ghose, M. K., Air pollution in the city of Kolkata: Health effects due to chronic exposure. In Air Pollution in Kolkata: An Analysis of Current Status and Interrelation between Different Factors; SEEU Review, Tetovo, Macedonia, 2013, vol. 8, pp. 181-214.

30. Farooqui, Z. M., John, K., Biswas, J. and Sule, N., Modeling analysis of the impact of anthropogenic emission sources on ozone concentration over selected urban areas in Texas. Atmos. Pollut. Res., 2013, 4, 33-42.

31. Mahato, S., Pal, S. and Ghosh, K. G., Effect of lockdown amid COVID-19 pandemic on air quality of the megacity Delhi, India. Sci. Total Environ., 2020, 730, 139086.

ACKNOWLEDGEMENTS. We thank OMI, VIIRS and CPCB teams for making satellite and in-situ observations freely available for scientific research. We acknowledge the use of HYSPLIT trajectory model for calculation of back trajectories. In-situ observation of $\mathrm{NO}_{x}$ over Dehradun is supported by ISRO.

doi: $10.18520 / \mathrm{cs} / \mathrm{v} 120 / \mathrm{i} 2 / 368-375$ 